\title{
Control of the senescence-associated secretory phenotype by NF-kB promotes senescence and enhances chemosensitivity
}

\author{
Yuchen Chien, ${ }^{1,9}$ Claudio Scuoppo, ${ }^{2,9}$ Xiaowo Wang, ${ }^{3}$ Xueping Fang, ${ }_{1}^{4}$ Brian Balgley, ${ }^{5}$ \\ Jessica E. Bolden, ${ }^{1}$ Prem Premsrirut, ${ }^{1}$ Weijun Luo, ${ }^{1}$ Agustin Chicas, ${ }^{1}$ Cheng S. Lee, ${ }^{4}$ \\ Scott C. Kogan, ${ }^{6}$ and Scott W. Lowe $\mathrm{e}^{1,7,8,10}$ \\ ${ }^{1}$ Cold Spring Harbor Laboratory, Cold Spring Harbor, New York 11724, USA; ${ }^{2}$ Watson School of Biological Sciences, Cold Spring \\ Harbor Laboratory, Cold Spring Harbor, New York 11724, USA; ${ }^{3}$ Ministry of Education (MOE) Key Laboratory of Bioinformatics, \\ Bioinformatics Division, Tsinghua National Laboratory for Information Science and Technology (TNLIST), Department of \\ Automation, Tsinghua University, Beijing 10084, China; ${ }^{4}$ Department of Chemistry and Biochemistry, University of Maryland, \\ College Park, Maryland 20742, USA; ${ }^{5}$ Calibrant, Gaithersburg, Maryland 20878, USA; ${ }^{6}$ Department of Laboratory Medicine, \\ Helen Diller Family Comprehensive Cancer Center, University of California at San Francisco, San Francisco, California 94143 , \\ USA; ${ }^{7}$ Howard Hughes Medical Institute, Cold Spring Harbor, New York 11724, USA; ${ }^{8}$ Cancer Biology and Genetics Program, \\ Memorial Sloan Kettering Cancer Center, New York, New York 10065, USA
}

Cellular senescence acts as a potent barrier to tumorigenesis and contributes to the anti-tumor activity of certain chemotherapeutic agents. Senescent cells undergo a stable cell cycle arrest controlled by RB and p53 and, in addition, display a senescence-associated secretory phenotype (SASP) involving the production of factors that reinforce the senescence arrest, alter the microenvironment, and trigger immune surveillance of the senescent cells. Through a proteomics analysis of senescent chromatin, we identified the nuclear factor- $\mathrm{k} B$ (NF-kB) subunit p65 as a major transcription factor that accumulates on chromatin of senescent cells. We found that NF-кB acts as a master regulator of the SASP, influencing the expression of more genes than RB and p53 combined. In cultured fibroblasts, NF- $\mathrm{kB}$ suppression causes escape from immune recognition by natural killer (NK) cells and cooperates with p53 inactivation to bypass senescence. In a mouse lymphoma model, NF- $\mathrm{kB}$ inhibition bypasses treatment-induced senescence, producing drug resistance, early relapse, and reduced survival. Our results demonstrate that NF-кB controls both cell-autonomous and non-cell-autonomous aspects of the senescence program and identify a tumor-suppressive function of NF- $\mathrm{KB}$ that contributes to the outcome of cancer therapy.

[Keywords: NF-кB; SASP; senescence; lymphoma; chemoresistance]

Supplemental material is available for this article.

Received June 22, 2011; revised version accepted September 1, 2011.

Cellular senescence is an anti-proliferative program that limits the propagation of damaged cells at risk of neoplastic transformation (Campisi and d'Adda di Fagagna 2007). Identified initially as the process that limits the replicative life span of cultured human cells, senescence also can be triggered acutely in cells by activated oncogenes, leading to "oncogene-induced senescence" that may halt the progression of premalignant lesions (Mooi

\footnotetext{
${ }^{9}$ These authors contributed equally to this work.

${ }^{10}$ Corresponding author.

E-mail lowes@mskcc.org.

Article published online ahead of print. Article and publication date are online at http://www.genesdev.org/cgi/doi/10.1101/gad.17276711.
}

and Peeper 2006). Furthermore, senescence can be activated by various forms of DNA damage, including that produced by cytotoxic chemotherapeutic agents (Schmitt et al. 2002; te Poele et al. 2002; Roninson 2003). Thus, in addition to acting as a potent barrier to tumorigenesis, senescence contributes to the cytotoxicity of certain anticancer agents, thus dictating the treatment outcome of chemotherapy (Kuilman et al. 2010).

Cells undergoing senescence have characteristic features, displaying a large and flat morphology, an increase in senescence-associated $\beta$-galactosidase (SA- $\beta$-gal) activity, and, in some cell types, a discernible change in chromatin organization known as senescence-associated heterochromatin foci (SAHF) (Kuilman et al. 2010). Molecularly, 
senescent cells undergo a stable cell cycle arrest executed by interplay between the RB and p53 tumor suppressor pathways (Serrano et al. 1997; Zhu et al. 1998) and, accordingly, often accumulate the $\mathrm{p} 16^{\mathrm{INK} 4 \mathrm{a}}, \mathrm{p} 15^{\mathrm{INK} 4 \mathrm{~b}}$, and $\mathrm{p} 21^{\mathrm{Cip} 1 / \text { Waf1 }}$ cyclin-dependent kinase inhibitors that engage the RB pathway or mediate p53 effects (Lin and Benchimol 1997; Woods et al. 1997; Malumbres et al. 2000). Together, these changes generate a repressive chromatin environment that leads to the stable repression of E2F-responsive genes (Narita et al. 2003).

In addition to executing a cell cycle arrest program, senescent cells undergo massive changes in the expression of genes that are predicted to influence the tissue microenvironment in vivo (Campisi and d'Adda di Fagagna 2007). Thus, in addition to the repression of proliferation genes, senescent cells often down-regulate extracellular matrix proteins and up-regulate extracellular matrix-degrading enzymes (Shelton et al. 1999). They also secrete a variety of inflammatory cytokines and other immune modulators (Freund et al. 2010). Collectively, these changes have been referred to as the senescence-associated secretory phenotype (SASP) or senescence messaging secretome (SMS) (Coppe et al. 2008; Kuilman and Peeper 2009).

Although components of the SASP were initially studied primarily as markers of senescence (Kortlever et al. 2006), it is now clear that SASP components actively participate in the senescence process. For example, key SASP factors, including interleukin-6 (IL-6) and IL-8, act in an autocrine feedback loop to reinforce the senescence growth arrest (Kortlever et al. 2006; Acosta et al. 2008; Kuilman et al. 2008). In addition, secreted factors from senescent cells may act in a paracrine manner to trigger senescence or, conversely, stimulate proliferation and/or transformation of adjacent immortalized cells (Krtolica et al. 2001; Wajapeyee et al. 2008). Finally, IL-6, IL-8, and other secreted factors attract immune cells that, together with the increased expression of immune cell-interacting molecules on senescent cells, can lead to immune surveillance and subsequent elimination of senescent cells. Depending on the biological context, this process can facilitate tumor regression or the resolution of wound healing responses (Xue et al. 2007; Krizhanovsky et al. 2008). Despite the potential importance of the SASP to the biology of senescence, little is known about how the process is regulated, and its impact on cancer phenotypes has not been directly assessed.

We and others have previously shown that senescent cells undergo massive changes in gene expression that are associated with chromatin modifications that, in some cell types, lead to marked changes in the binding of transcription factors and other chromatin modifiers, including RB, p53, and the high-mobility group A proteins (HMGA1 and HMGA2) (Narita et al. 2003, 2006; Zhang et al. 2007). Here we perform a nonbiased analysis of proteins bound to chromatin in senescent cells and identify the nuclear

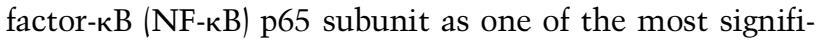
cantly enriched transcriptional modifiers that bind senescent cell chromatin. We find that NF- $\mathrm{BB}$ is a master regulator of the SASP and then use this to further probe the impact of SASP biology on the senescence program.

\section{Results}

Identification and activation of NF- $\mathrm{B}$ in senescent cells

To identify novel factors that contribute to the regulation of cellular senescence, we performed global proteomics analyses of chromatin compositions of both growing and oncogenic H-Ras ${ }^{\mathrm{V} 12}$-induced senescent IMR-90 fibroblasts, a well-characterized system of cellular senescence (Campisi 2005). From two independent sample sets, we identified 2362 proteins that were reproducibly enriched in the chromatin fraction of senescent IMR-90 cells, including senescence benchmark proteins HMGA1 and HMGA2 (Supplemental Material; Supplemental Table 1) (Narita et al. 2006). Other known senescence regulators we identified as more tightly associated with senescent chromatin include the promyelocytic leukemia protein (PML) and CCAAT/enhancer-binding protein $\beta$ (C/EBP $\beta$ ) (Ferbeyre et al. 2000; Pearson et al. 2000; Kuilman et al. 2008). We did not detect the presence of p53 or RB in either growing or senescent chromatin, suggesting these factors fell below the limit of detection of this method (data not shown).

We chose to initially focus on transcription factors whose up-regulation might coordinate gene expression changes that drive senescence. Among the 18 transcription factors we identified, the p65 subunit of NF-кB stood out for its strong accumulation on senescent chromatin and its link to genes known to contribute to senescence and the SASP (Fig. 1A). Interestingly, the vast majority of work on NF-кB has demonstrated pro-oncogenic functions, although a role for NF- $\mathrm{B}$ in anti-proliferative responses has been documented in some contexts as well (Basseres and Baldwin 2006). Nonetheless, the potential contribution of NF- $\mathrm{kB}$ to senescence remains controversial, as some studies suggest a role in regulation of SASP targets, while others indicate that enforced NF- $\kappa$ B expression can bypass senescence (Acosta et al. 2008; Batsi et al. 2009; Wang et al. 2009; Rovillain et al. 2011). Given the striking accumulation of p65 in chromatin during senescence, we decided to explore its action in a systematic way.

NF- $\kappa \mathrm{B}$ complexes involve dimerization of five members-p65 (RelA), RelB, c-Rel, p50/p105 (NF-кB1), and p52/p100 (NF-кB2) - the most common form being a dimer composed of p50 and p65 subunits (Hoffmann and Baltimore 2006). NF- $\mathrm{B}$ is kept inactive through its sequestration in the cytoplasm by the inhibitor of $\kappa \mathrm{B}(\mathrm{I \kappa B})$ family of proteins. Upon signals elicited by bacterial products, cytokines, viral expression, growth factors, and stress stimuli, kinases catalyze the phosphorylation of IкB and the p65 subunit, triggering p65 release and the translocation of $\mathrm{p} 65 / \mathrm{p} 50$ transcription factors into the nucleus, where they activate a range of genes involved in immune and inflammatory responses (Wan and Lenardo 2009).

Consistent with the proteomics results, immunoblotting confirmed that p65 accumulated on chromatin in senescent cells (Fig. 1B). Moreover, immunoblotting with phospho-specific antibodies indicated that p 65 was phosphorylated on Ser 536, and immunofluorescence showed that p65 accumulated in the nucleus of SAHF-positive 
A

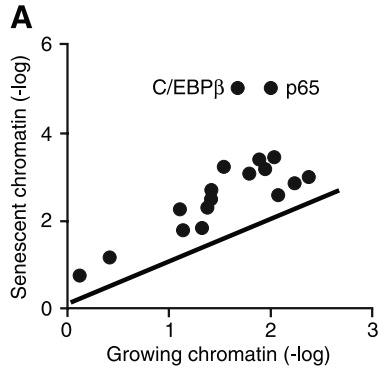

D

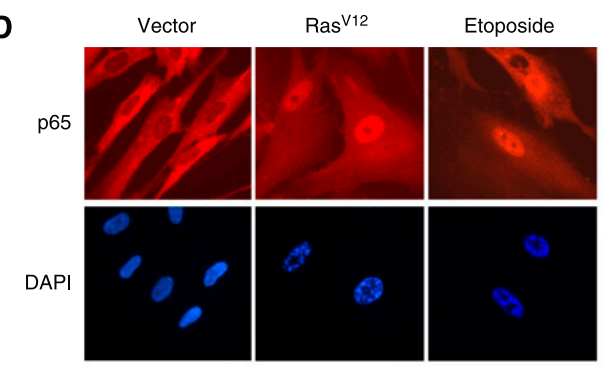

$\mathbf{F}$

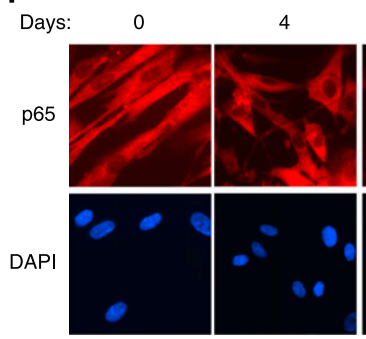

B
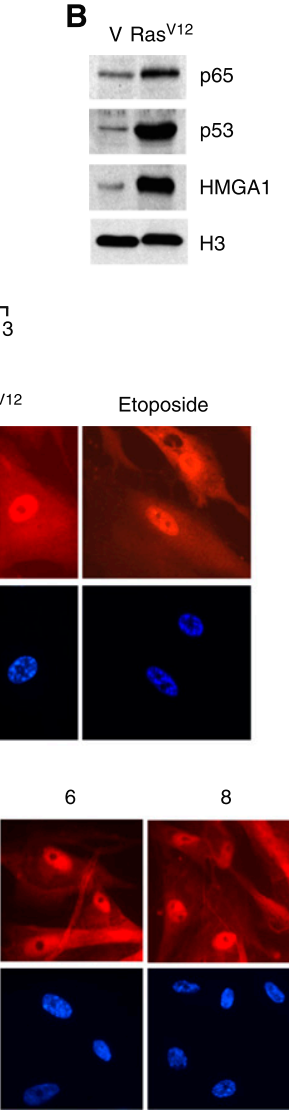

C

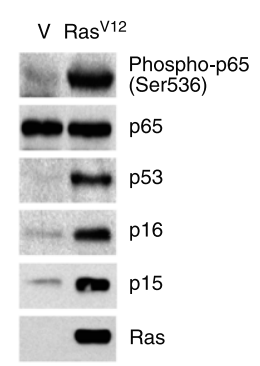

E

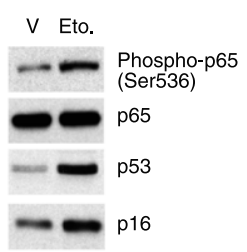

G

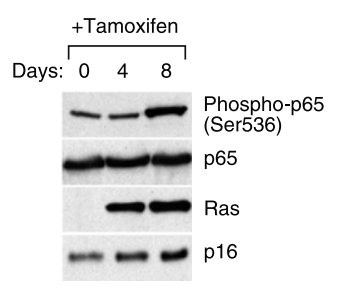

Figure 1. NF- $\mathrm{kB}$ is activated in senescent cells. $(A)$ A scatter plot of 18 transcription factors identified from mass spectrometry (refer to Supplemental Table 1 for the full list of proteins identified). The line represents values of $y=x$, which means the expression is the same for growing and senescent cells. (B) Increased binding of p65 to senescent chromatin fraction. Chromatin fractions were isolated from growing (containing empty vector, abbreviated as V) and senescent IMR-90 cells induced by $\mathrm{H}$-Ras ${ }^{\mathrm{V} 12}$ and analyzed by Western blotting using the indicated antibodies. $\mathrm{H} 3$ was used as loading control. (C) Hyperphosphorylation of p65 on Ser 536 in senescent cells. Whole-cell lysates from growing and $\mathrm{H}-\mathrm{Ras}^{\mathrm{V} 12}$-induced senescent IMR-90 cells were analyzed by Western blotting using the indicated antibodies. Accumulation of $\mathrm{p} 53, \mathrm{p} 16^{\mathrm{INK} 4 \mathrm{a}}$, and $\mathrm{p} 15^{\mathrm{INK} 4 \mathrm{~b}}$ proteins are shown as senescence markers. Total p65 was used as loading control. $(D)$ Senescent cells show nuclear translocation and accumulation of $\mathrm{p} 65$. Growing and senescent IMR-90 cells induced by either H-Ras ${ }^{\mathrm{V} 12}$ or etoposide $(100 \mu \mathrm{M})$ were immunostained with anti-p65 antibodies (top panels) and counterstained with DAPI (bottom panels) to show SAHF formation. (E) Whole-cell lysates from growing and etoposide-induced senescent IMR-90 cells were analyzed by Western blotting using the indicated antibodies. $(F) \mathrm{Nu}$ clear translocation of $\mathrm{p} 65$ coincides with senescence. IMR-90 cells containing Ras ${ }^{\mathrm{V} 12}$-ER were treated with 4-OHT $(200 \mu \mathrm{M})$ for the indicated time. Cells were immunostained with anti-p65 antibodies (top panels) and counterstained with DAPI (bottom panels). (G) Whole-cell lysates from cells in parallel with conditions described in $F$ were collected and analyzed by Western blotting using the indicated antibodies.

cells during senescence, suggesting p65 activation (Fig. $1 \mathrm{C}, \mathrm{D})$. Importantly, nuclear translocation and accumulation of p65 occurred in senescent IMR-90 cells triggered to senesce by either oncogenic H-Ras ${ }^{\mathrm{V} 12}$ or the chemotherapeutic drug etoposide, suggesting that activation of NF-кB in senescent cells is independent of the specific senescence trigger used (Fig. 1D,E).

We also examined the kinetics of NF- $\mathrm{B}$ activation during senescence by expressing a 4-hydroxy-tamoxifen (4-OHT)-inducible estrogen receptor (ER) module fused to H-Ras ${ }^{\text {V12 }}$ (H-Ras ${ }^{\text {V12 }}$-ER). IMR-90 cells became senescent after $6 \mathrm{~d}$ of induction of $\mathrm{H}-\mathrm{Ras}{ }^{\mathrm{V} 12}$ by $4-\mathrm{OHT}$, as indicated by the formation of SAHF and accumulation of $\mathrm{p} 16^{\text {INK4a }}$ (Fig. 1F,G). Notably, NF-кB activation, as assessed by $\mathrm{p} 65$ nuclear accumulation and phosphorylation, was clearly detectable after $6 \mathrm{~d}$ of induction of H-Ras ${ }^{\mathrm{V} 12}$, which coincided with cell cycle exit and SAHF formation (Fig. 1F,G; Narita et al. 2003). Therefore, in this setting, NF-kB activation is likely an indirect consequence of Ras signaling and coincides with the onset of senescence.

\section{$N F-\kappa B$ controls the SASP}

To address the function of NF- $\mathrm{B}$ during senescence, we examined the consequences of suppressing p65 function on senescence phenotypes using RNAi. We designed several miR30-based shRNAs against p65, and two efficiently knocked down p65 protein levels in IMR-90 cells (Fig. 2A). In IMR-90 cells, this level of p65 knockdown was not sufficient to bypass senescence (see Fig.3). Such a result is not particularly surprising, as knockdown of no single senescence regulator has been shown to bypass the arrest program in IMR-90 fibroblasts (Serrano et al. 1997; Campisi 2005; Narita et al. 2006). This situation enabled us to identify potential targets of NF- $\kappa \mathrm{B}$ during senescence while avoiding any potentially confounding variation in proliferative states between cells triggered to senesce in the presence or absence of functional NF-кB.

Transcriptional profiling was performed on growing or H-Ras ${ }^{\mathrm{V} 12}$-induced senescent IMR-90 cells expressing shRNAs targeting p65, p53, or the nonexpressed protein firefly luciferase (Luc) as a control. RNA from two independent experiments was hybridized to the Affymetrix Human Genome U133 Plus 2.0 microarrays. Data were also compared with a published data set that identified RB-regulated genes in senescence (Chicas et al. 2010). We identified 406 genes that were consistently differentially expressed (greater than twofold change) upon p65 loss in senescent cells, whereas in growing cells, only 24 genes were similarly affected. In addition, while 289 genes failed to be induced upon suppression of p65 in senescent cells, suppression of p53 and RB down-regulated only 85 and 215 
A

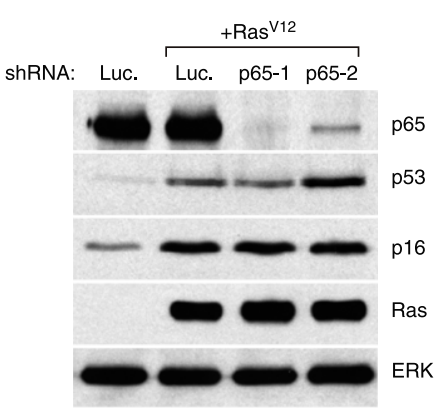

$\mathbf{C}_{10}$

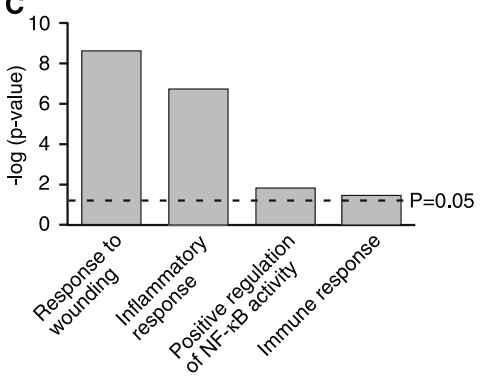

E

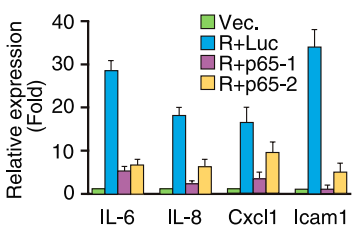

$\mathbf{F}$

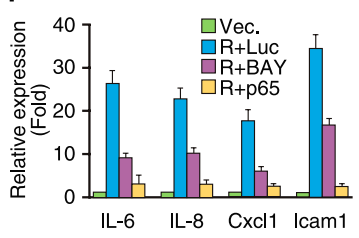

B

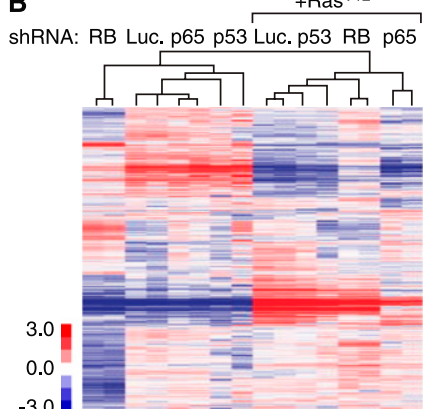

D

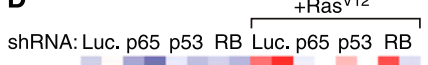

shRNA: Luc. p65 p53 RB Luc. p65 p53 RB

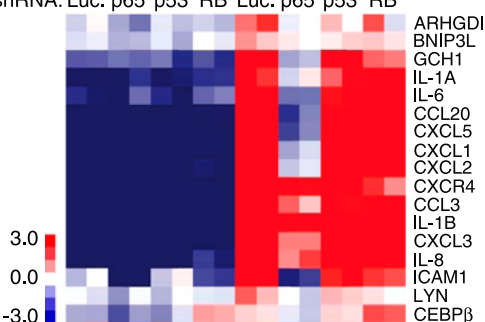

G

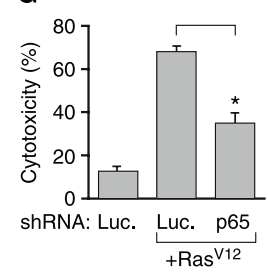

Figure 2. NF- $\mathrm{kB}$ mediates the SASP. (A) IMR-90 cells were infected with the indicated shRNAs with or without H-Ras ${ }^{\mathrm{V} 12}$. shRNA against firefly luciferase (Luc.) was used as a control. Whole-cell lysates were collected $8 \mathrm{~d}$ following the completion of selection and analyzed by Western blotting using the indicated antibodies. Total ERK was used as loading control. $(B)$ Hierarchical clustering analysis of differentially expressed genes from IMR-90 cells expressing each indicated shRNA with and without $\mathrm{H}-\mathrm{Ras}{ }^{\mathrm{V} 12}$. The shRNA against p65 that showed the best knockdown efficiency by Western blotting (shp65-1) was used. (C) GO analysis of significantly down-regulated genes upon loss of p65 function $(P<$ $0.05)$. Differentially expressed genes were identified by comparing samples with shRNA against p65 with that of luciferase in $\mathrm{H}$-Ras ${ }^{\mathrm{V} 12}$-induced senescent IMR-90 cells. (D) Heat map of genes comprising the GO term "immune response." Loss of p65 significantly down-regulated immune response genes $\left(P=3.7 \times 10^{-2}\right.$ with Benjamini correction). (E) Suppression of p65 function abrogates the induction of IL-6, IL-8, CXCL1, and ICAM-1 in senescent cells. Total RNA was extracted and analyzed by RT-qPCR with primer sets against the indicated transcripts. Expression is normalized to the expression of $\beta$-actin and is expressed as the fold change relative to growing IMR-90 cells. Values are means + SEM of two independent samples with triplicate qPCR. (Vec.) Vector; (R.) H-Ras ${ }^{\mathrm{V} 12}$; (Luc.) shRNA against luciferase; (p65-1 and p65-2) two shRNAs against p65. (F) NF- $\mathrm{B}$ inhibitor BAY11-7082 (BAY) also prevents the induction of IL-6, IL-8, CXCL1, and ICAM-1 in senescent cells. IMR-90 cells were infected with the indicated shRNAs with or without $\mathrm{H}-\mathrm{Ras}^{\mathrm{V} 12}$. Eight days following the completion of selection, senescent IMR-90 cells were treated with $10 \mu \mathrm{M}$ BAY11-7082 for $2 \mathrm{~d}$ before harvesting. Expression is normalized to the expression of $\beta$-actin and is expressed as the fold change relative to growing cells (containing vector). Values are means + SEM of two independent samples with triplicate qPCRs. $(G)$ NF-кB is required for recognition and killing by NK cells. IMR-90 cells expressing the indicated vectors were cocultured with YT cells (a human NK cell line) for $12 \mathrm{~h}$. Attached viable senescent cells were stained with crystal violet. Crystal violet quantification at OD 595 was performed and the percentage cytotoxicity was calculated as crystal violet absorbance in the presence of YT cells relative to senescent cells cultured in the absence of YT cells. Values represent means + SEM of three independent experiments; $\left({ }^{\star}\right) P<0.05$ using Student's $t$-test.

genes, respectively. Unsupervised hierarchical clustering of the arrays using the sets of differentially expressed genes segregated the samples into two large classes: without $\mathrm{H}_{-R a s^{\mathrm{V} 12}}$ (growing) and with H-Ras ${ }^{\mathrm{V} 12}$ (senescent) (Fig. 2B). Although cells expressing RB shRNAs were the most distant clusters in growing cells, additional clustering of the genes within the senescent group clearly segregated cells expressing p65 shRNAs from those expressing control (Luc), p53, or RB shRNAs. Indeed, a more detailed analysis of E2F target genes, which are negatively regulated by RB (Chen et al. 2009), indicates that NF-кB has little impact on their expression (Supplemental Fig. 1), consistent with each factor controlling parallel pathways.

To broadly characterize the cellular processes altered upon disruption of NF- $\kappa \mathrm{B}$ in senescent cells, we tested for enrichment of gene ontology (GO) terms. Unbiased GO analysis of these down-regulated genes showed a significant enrichment $(P<0.05$ with Benjamini correction) for a total of $47 \mathrm{GO}$ terms, including "positive regulation of NF-кB activity" (Fig. 2C). One of the significant GO terms was "immune response," which comprised 17 genes, including $I L-6, I L-8, C X C L 1$, and ICAM1 (Fig. 2D). Importantly, these genes were shown by RT-qPCR to be affected by NF- $\mathrm{B}$ inhibition in cells expressing p65 shRNAs or treated with the NF-kB inhibitor BAY 11-7082 (Fig. 2E,F). Other known SASP components, including several matrix metalloproteinases and noninflammatory response genes, also failed to be induced in p65 shRNAexpressing cells triggered to senesce (Supplemental Table 2). Therefore, while NF-кB suppression has a limited impact on gene expression in normal growing cells, it has a major impact on global gene expression in senescent cells, controlling a transcriptional module that is larger and distinct from those controlled by the established senescence regulators $\mathrm{p} 53$ and $\mathrm{RB}$.

The fact that the expression of many immune modulatory genes and secreted factors depends on NF-кB expression raises the possibility that it promotes immune surveillance of senescent cells-a non-cell-autonomous component of the senescence program. Indeed, senescent 
A

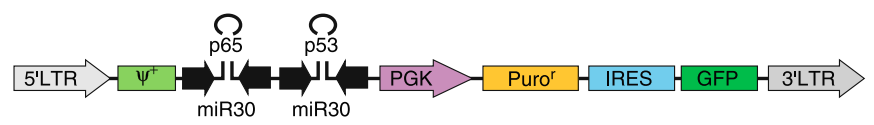

B

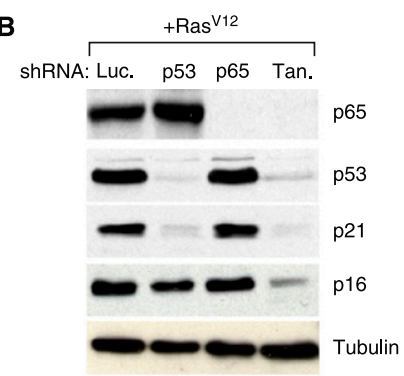

D
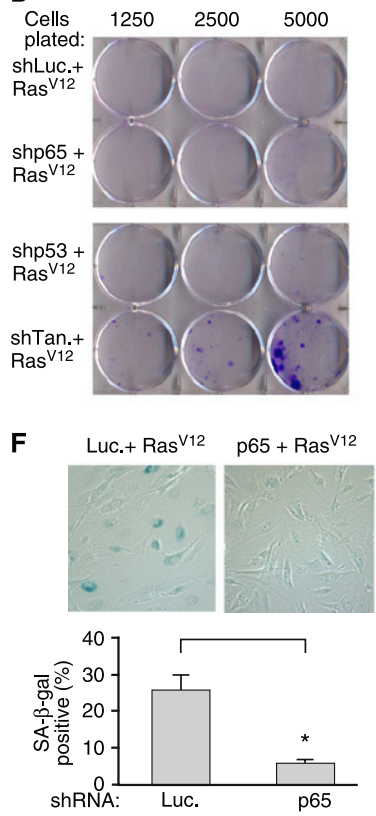

C

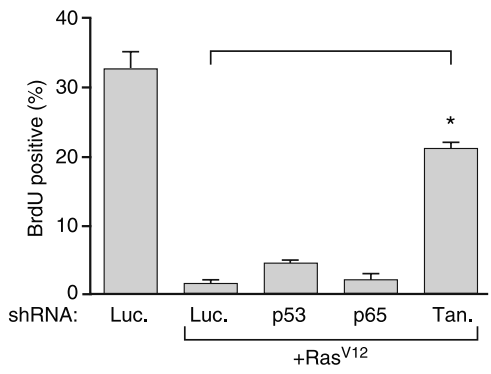

E
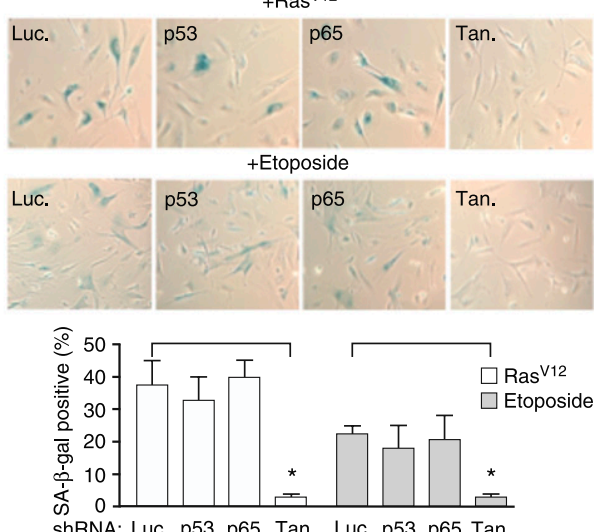

G

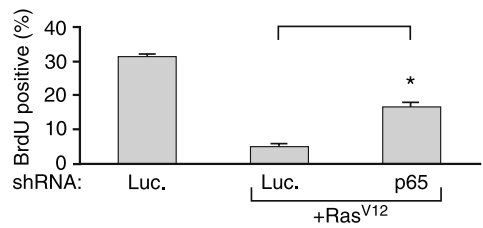

Figure 3. NF-кB cooperates with p53 to promote senescence. (A) A schematic diagram of the polycistronic shRNA construct used to simultaneously knock down p65 and p53. (Tan) Tandem hairpin. The shRNA against p65 that showed the best knockdown efficiency by Western blotting (shp651) was used. (B) Coinhibition of p53 and p65 expression. IMR-90 cells were infected with the indicated shRNAs and H-Ras ${ }^{\mathrm{V} 12}$. Whole-cell lysates were collected $8 \mathrm{~d}$ post-selection and analyzed by Western blotting using the indicated antibodies. Tubulin is shown as a loading control. $(C)$ Coinhibition of p53 and $\mathrm{p} 65$ bypasses senescence. IMR-90 cells infected with the indicated shRNAs with or without $\mathrm{H}-\mathrm{Ras}^{\mathrm{V} 12}$ were analyzed for BrdU incorporation 8 d post-selection. Values represent means + SEM of two independent experiments; $\left(^{*}\right) P<0.005$ using Student's $t$-test. ( $D$ ) IMR-90 cells infected with the indicated shRNAs and $\mathrm{H}-\mathrm{Ras}^{\mathrm{V} 12}$ were plated at increasing cell density $8 \mathrm{~d}$ post-selection. Cells were cultured for an additional 2 wk, stained with crystal violet, and analyzed for colony formation. (E) IMR90 cells were infected with the indicated shRNAs and triggered to undergo senescence by either $\mathrm{H}-\mathrm{Ras}^{\mathrm{V} 12}$ or $100 \mu \mathrm{M}$ etoposide. Eight days postselection, cells were assayed for SA- $\beta$-gal activity. Values represent means + SEM of three independent experiments; $\left({ }^{\star}\right) P<0.05$ using Student's $t$-test. $(F) \mathrm{BJ}$ cells were infected with the indicated shRNAs together with $\mathrm{H}-\mathrm{Ras}^{\mathrm{V} 12}$ to trigger senescence. Cells were assayed for SA- $\beta$-gal activity $8 \mathrm{~d}$ post-selection. Values represent means + SEM of three independent experiments; $\left(^{*}\right) P<0.05$ using Student's $t$-test. $(G)$ BJ cells were infected with the indicated shRNAs with or without $\mathrm{H}-\mathrm{Ras}^{\mathrm{V} 12}$. Cells were assayed for BrdU incorporation $8 \mathrm{~d}$ post-selection. Values represent means + SEM of three independent experiments; $\left(^{\star}\right) P<0.05$ using Student's $t$-test.
IMR-90 cells become hypersensitive to targeting by natural killer (NK) cells as assessed by short-term cytotoxicity assays in vitro (Krizhanovsky et al. 2008), an effect that was strongly impaired by suppression of $\mathrm{p} 65$ (Fig. 2G). Together, our results indicate that NF-кB controls a discrete transcriptional module that influences non-cell-autonomous aspects of the senescence program.

\section{$N F-\kappa B$ cooperates with p53 to promote senescence}

Our transcriptional profiling data suggest that NF-кB controls a distinct transcriptional module compared with that regulated by $\mathrm{p} 53$. To test whether these regulators cooperate during senescence, we developed a polycistronic shRNA construct (Chicas et al. 2010) capable of cosuppressing p53 and p65 (Fig. 3A). Similar levels of p53 and p65 knockdown were achieved with the "tandem" hairpin in senescent IMR-90 cells, demonstrating that the efficiency of the tandem construct was equivalent to that of the individual hairpins (Fig. 3B). While inhibiting p53 or p65 expression alone had no overt effect on the growth arrest phenotype induced by oncogenic H-Ras ${ }^{\mathrm{V} 12}$ in IMR-
90 cells, inhibiting both p53 and p65 simultaneously promoted cell growth as measured by reduced accumulation of $\mathrm{p} 16^{\text {INK4a }}$ protein (Fig. 3B), an increase in cyclin A protein (Supplemental Fig. 2), increased 5-bromo-2'deoxyuridine (BrdU) incorporation (Fig. 3C), and an increased ability of cells to form colonies when seeded at limiting dilution (Fig. 3D). Consistent with this observation, cells cosuppressing p53 and p65 failed to induce SA- $\beta$-gal (Fig. 3E). Comparable results were observed using either oncogenic $\mathrm{H}$-Ras ${ }^{\mathrm{V} 12}$ or etoposide as a senescence stimulus (Fig. 3E).

These above results suggest that the molecular programs regulated by NF- $\kappa \mathrm{B}$ are complementary to those controlled by $\mathrm{p} 53$. Nonetheless, such interactions may be cell typespecific, as p65 shRNAs were sufficient to bypass $\mathrm{H}$-Ras ${ }^{\mathrm{V} 12}$-induced senescence in human $\mathrm{BJ}$ fibroblasts upon loss of p65 function (Fig. 3F,G), perhaps owing to the less robust senescence program in this cell type (Beausejour et al. 2003). Accordingly, suppression of the NF- $\mathrm{kB}$ target IL-6 can impair senescence in human diploid fibroblasts containing shRNAs against p16 ${ }^{\mathrm{INK} 4 a}$ (Kuilman et al. 2008). These results imply that in addition to influencing the 
non-cell-autonomous aspects of the senescence program, NF-кB can contribute to the cell cycle arrest as well.

\section{Modulation of NF- $\kappa B$ activity in lymphomas using tetracycline-regulatable p 65 shRNA}

In addition to its role in preventing tumorigenesis, cellular senescence can contribute to the anti-cancer activity of certain chemotherapeutic drugs, particularly in circumstances in which apoptosis is suppressed (Roninson 2003). For example, $E \mu$-myc lymphomas expressing the antiapoptotic protein Bcl-2 undergo senescence in response to cytotoxic chemotherapy, which contributes to enhanced survival in mice compared with animals harboring lymphomas with defective senescence machinery (Schmitt et al. 2002). To examine the contribution of NF-kB to cellular senescence in vivo, we developed two novel platforms that enabled us to conditionally regulate endogenous NF- $\kappa$ B activity in murine lymphomas in vivo. One system involved the production of transgenic mice harboring tetracycline-responsive p65 shRNA targeted to the ColA1 locus by recombination-mediated cassette exchange in embryonic stem (ES) cells, which provided a highly efficient system for producing mice in which endogenous gene expression can be controlled in a constitutive or tissue-restrictive manner in transgenic mice (Premsrirut et al. 2011). The other system involved a more flexible variation of the $E \mu$-myc model produced by retrovirally cotransducing $c-M y c$ and $B c l-2$ directly into pre-B cells rather than expressing each from a tissuespecific transgene. We envisioned that combination of these systems would enable the rapid production of leukemias/lymphomas in which endogenous NF-кB expression could be controlled in vivo, avoiding extensive intercrossing of genetically engineered strains.

Bone marrow was isolated from transgenic mice carrying the Rosa reverse tetracycline-controlled transcriptional activator (Rosa-rtTA) and a tetracycline-responsive p65 miR30 design shRNA (TRE-shRNA) linked to green fluorescence protein (GFP). Cells were retrovirally transduced with a construct coexpressing both Bcl-2 and c-Myc (Fig. 4A) and maintained in culture conditions known to support pre-B-cell growth (Whitlock and Witte 1987). Importantly, these cells achieved substantial p65 knockdown after $6 \mathrm{~d}$ of doxycycline (Dox) treatment in culture (Fig. 4B).

Following transplantation of these cells into multiple nontransgenic, sublethally irradiated recipient mice (BL6) Ly5.1), recipient animals developed palpable prescapular and cervical lymph nodes and a marked lymphocytosis and splenomegaly within $3 \mathrm{wk}$ (data not shown). Each animal displayed pathology consistent with an acute lymphoblastic leukemia/lymphoma leading to lymph node effacement (Fig. 4C), involvement of splenic white and red pulp (Fig. 4D), and infiltration in perivascular areas of the liver (Fig. 4E).

A notable feature of the lymph node histopathology was a low number of tingible body macrophages, suggesting the presence of few apoptotic cells (data not shown). Accordingly, the lymphoma cells were refractory to killing by adriamycin (ADR), a chemotherapeutic agent
A

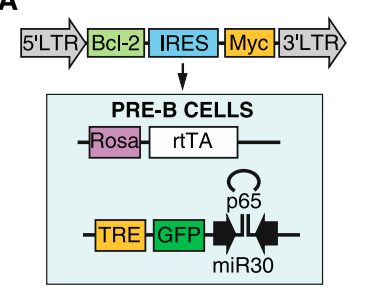

B

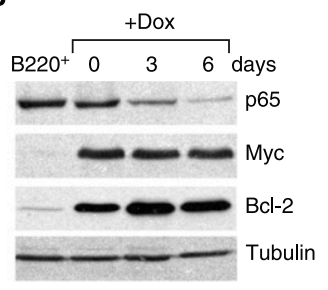

C

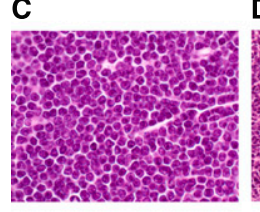

D

E
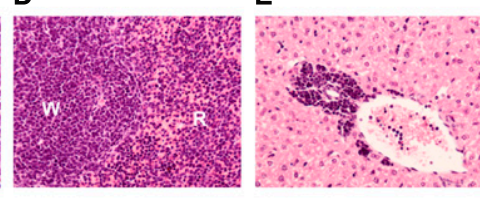

$\mathbf{F}$
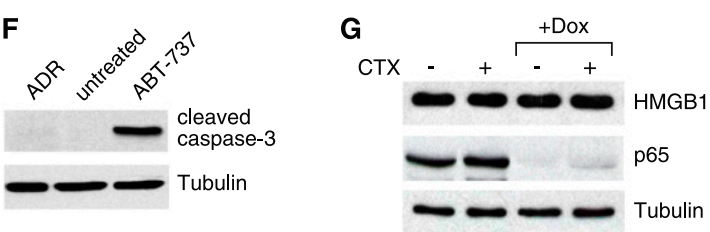

Figure 4. Generation of Myc-Bcl-2-driven lymphomas with a tetracycline-regulatable p65 shRNA. (A) Bone marrow from 4- to 5-wk-old female mice carrying the Rosa-rtTA and the TREshRNA were infected with a vector coexpressing Myc and Bcl-2. Cells were explanted into pre-B-cell culture medium containing IL-7 for 1 wk. (B) Efficient knockdown of p65 after $6 \mathrm{~d}$ of Dox treatment. Cells from $A$ were treated with or without Dox $(1 \mu \mathrm{g} /$ $\mathrm{mL}$ ) for the indicated time, and whole-cell lysates were collected and analyzed by Western blotting using the indicated antibodies. Sorted $\mathrm{B} 220^{+}$cells from wild-type animals were used as a control. $(C-E)$ Lymphoblastic neoplasms in recipient animals. Hematoxylin and eosin staining of lymph node $(C)$, spleen $(D)$, and liver $(E)$ shows lymphoblastic disease. (W) Splenic white pulp; (R) splenic red pulp; lymphoma infiltrates both. (F) Myc- and Bcl-2-driven pre$\mathrm{B}$ cells are resistant to apoptosis induced by chemotherapeutic agents. Cells from $A$ were left untreated or treated with either ADR $(250 \mathrm{ng} / \mathrm{mL})$ or ABT-737 $(10 \mu \mathrm{M})$ for $24 \mathrm{~h}$ in vitro. Whole-cell lysates were collected and analyzed by Western blotting using the indicated antibodies. $(G)$ Treatment with chemotherapeutic agents does not engage necrosis in vivo. On and off Dox lymphomabearing mice were left untreated or treated with a single $200-\mu \mathrm{L}$ dose of CTX $(30 \mathrm{mg} / \mathrm{mL})$. After $7 \mathrm{~d}$, lymph nodes were harvested, prepared for single-cell suspension, sorted for $\mathrm{CD} 43^{-} \mathrm{B}$ cells, and analyzed by Western blotting using the indicated antibodies.

commonly used to treat human B-cell malignancies, and failed to induce the apoptotic effector cleaved caspase-3 at the time points examined (Fig. 4F). As expected, however, these cells remained sensitive to the Bcl-2 antagonist ABT-737 (Mason et al. 2008). In vivo, treatment with cyclophosphamide (CTX) also did not trigger substantial apoptosis (data not shown) or release of the necrotic marker high-mobility group box 1 (HMGB1) protein (Fig. 4G; Scaffidi et al. 2002; Zong et al. 2004). However, as previously described, CTX treatment resulted in the induction of senescence as measured by accumulation of the senescence marker $\mathrm{p} 15^{\mathrm{INK} 4 \mathrm{~b}}$ (Fig. 5A) and SA- $\beta$-gal staining (Fig. 5B). Therefore, these B-cell malignancies provide a suitable context to interrogate therapyinduced senescence using inducible shRNAs. 
A

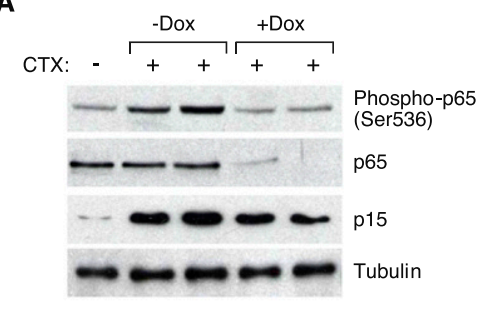

C

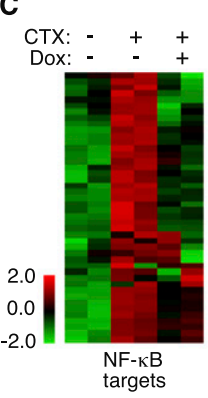

D

E

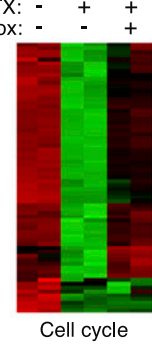

B

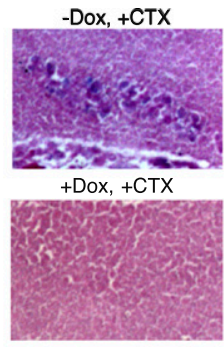

$\mathbf{F}$
E

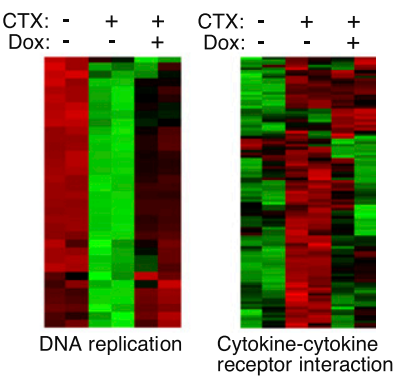

G

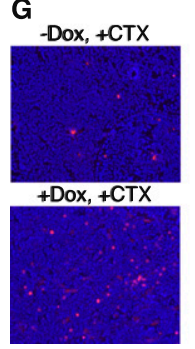

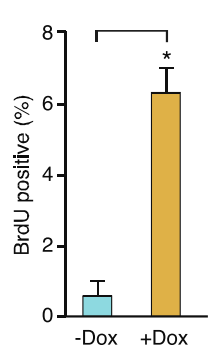

H

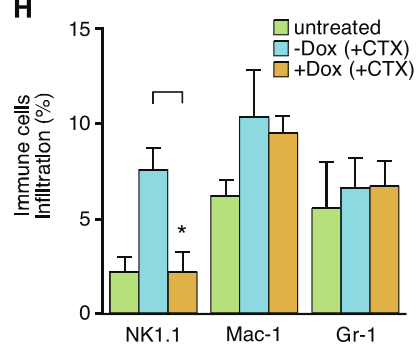

Figure 5. NF-кB inhibition compromises drug-induced senescence. (A) Activation of NF-кB occurs in chemotherapy-induced senescent lymphomas. Lymphoma-bearing mice with or without Dox treatment were injected with a single $200-\mu \mathrm{L}$ dose of CTX $(30 \mathrm{mg} / \mathrm{mL})(\mathrm{n}=2$ for each condition, except the CTXuntreated control). Lymph nodes from these mice were harvested and sorted for CD43- B cells, and whole-cell lysates were prepared and analyzed by Western blotting using the indicated antibodies. (B) Loss of p65 function bypasses drug-induced senescence. Seven days after CTX injection, lymph nodes from off Dox (p65-expressing) and on Dox (p65 knockdown) mice were harvested, cryo-sectioned, analyzed for SA- $\beta$-gal activity, and counterstained with eosin. $(C-F)$ Heat map of differentially expressed NF- $\mathrm{kB}$ targets $(C)$, cell cycle $(D)$, DNA replication $(E)$, and cytokine-cytokine receptor interaction genes $(F)$ in each indicated condition (refer to Supplemental Table 3 for the full list of genes). ( $G$ ) Inhibiting p65 function promotes cell growth after CTX treatment. Seven days after CTX injection, off Dox (p65-expressing) and on Dox (p65 knockdown) mice were injected intraperitoneally (i.p.) with $200 \mu \mathrm{L}$ of BrdU solution $(10 \mathrm{mg} / \mathrm{mL})$ and sacrificed $2 \mathrm{~h}$ later. Lymph nodes from these mice were harvested, cryo-sectioned, immunostained for BrdU (red), and counterstained with DAPI (blue). Values represent means + SEM of at least three independent animals; $\left(^{*}\right) P<0.05$ using Student's $t$-test. $(H)$ Loss of p65 function abrogates NK cell infiltration. Seven days after CTX injection, lymph nodes from off Dox (p65-expressing) and on Dox (p65 knockdown) mice were harvested, and single-cell suspensions were prepared and analyzed for the presence of specific immune cell types by flow cytometry. Percentages of total CD $45.2^{+}$cells are indicated. Values represent means + SEM of at least three independent animals; $\left(^{\star}\right) P<0.05$ using Student's $t$-test.

\section{NF- $\mathrm{KB}$ contributes to chemotherapeutic drug-induced senescence}

To examine the effect of NF- $\mathrm{BB}$ inhibition on drug-induced senescence in vivo, we transplanted the pre-B-cell cultures described above into nontransgenic, sublethally irradiated recipient mice (BL6/Ly5.1). Lymphoma-bearing mice were left untreated or treated with Dox to induce shRNAs targeting p65. Two weeks later, mice were then injected with a single dose of CTX to induce a senescence response, and monitored for NF-кB activation as well as the impact of NF-кB suppression on senescence.

Consistent with our results in human fibroblasts, p65 phosphorylation was induced by chemotherapy in vivo (Fig. 5A). Furthermore, lymphomas from mice on Dox (harboring lymphomas with suppressed p65 expression) showed less accumulation of $\mathrm{p} 15^{\mathrm{INK} 4 \mathrm{~b}}$ protein (Fig. 5A) and no apparent SA- $\beta$-gal staining (Fig. 5B) $7 \mathrm{~d}$ after CTX treatment, with no obvious differences in the amount of apoptosis and necrosis detected (data not shown). Of note, suppression of $\mathrm{p} 65$ had no impact on cell proliferation of Arf ${ }^{-/-}$E $\mu$-myc lymphomas treated with chemotherapy in vitro, a setting where drug treatment produces an apoptotic response rather than senescence (Supplemental Fig. 3; Schmitt et al. 1999). Thus, in a setting where apoptosis is suppressed, silencing NF-кB expression impairs the senescence response to chemotherapy in vivo.

We isolated lymphomas from mice to examine global gene expression using Affymetrix Mouse Gene 1.0 ST arrays. We found NF-кB was consistently activated $7 \mathrm{~d}$ after CTX treatment, as evidenced by increased transcription of a series of NF- $\mathrm{BB}$ target genes (target list from http://bioinfo.lifl.fr/NF-KB) $(P<0.05)$ (Fig. 5C), some of which were confirmed by RT-qPCR (data not shown). Moreover, GO analysis indicated that at this late time point the most significantly down-regulated genes in CTXtreated lymphomas were linked to the cell cycle $(P=1.10 \times$ $\left.10^{-9}\right)$ and DNA replication $\left(P=4.58 \times 10^{-12}\right)$ (Fig. 5D,E), while the most significantly up-regulated genes were related to the immune response $(P=0.02)$ and included key SASP components (Fig. 5F). Interestingly, CTX-treated lymphomas with attenuated p65 expression showed increased expression of cell cycle $\left(P=1.53 \times 10^{-8}\right)$ and DNA replication $\left(P=8.14 \times 10^{-10}\right)($ Fig. $5 \mathrm{D}, \mathrm{E})$ genes, but suppressed expression of immune response-related genes $(P=0.02)$ (Fig. 5F). In addition, these lymphomas incorporated more BrdU (Fig. 5G) and showed less infiltration of immune cells, especially NK cells (Fig. 5H), following chemotherapy. Together, these results are consistent with those observed in IMR-90 cells, where NF-кB influenced both cell-autonomous and non-cell-autonomous components of the senescence program.

\section{Disruption of NF- $\kappa$ B leads to chemoresistance and reduced survival}

To address the significance of NF-кB suppression on treatment outcome in murine lymphomas expressing c-Myc and Bcl-2, we monitored lymphoma progression in diseased animals following chemotherapy. Lymphoma-bearing mice were left off Dox or put on Dox to induce GFP fluorescence 
and p65 shRNA expression. Notably, no difference in the progression of established lymphomas was observed when NF- $\mathrm{kB}$ activity was inhibited by the p65 shRNA as assessed by peripheral lymph node enlargement and spleen size (data not shown). Mice were then treated with a single injection of CTX and monitored for disease regression, relapse, and survival.

When p65 levels were unaltered (off Dox), lymphomas responded rapidly to CTX by regressing to a nondetectable stage after $3 \mathrm{wk}$. In contrast, mice expressing the p65 shRNA (on Dox) displayed virtually no response to CTX as assessed by lymph node palpation (Fig. 6A). This result was not due to unanticipated effects of Dox treatment, since mice harboring an independent lymphoma containing shRNA against Renilla luciferase responded normally to chemotherapy in the presence of Dox (Supplemental Fig. 4). Consistent with the nonresponsiveness of lymphomas expressing p65 shRNAs to chemotherapy, mice harboring these lymphomas showed a dramatically reduced survival compared with controls (Fig. 6B).

Whole-body fluorescence imaging of mice after $3 \mathrm{wk}$ of CTX treatment indicated that shp65-expressing lymphomas (which are GFP positive) had overrun the lymph nodes, bones, and other organs of recipient mice that matched the anatomical locations of lymphoma pathology (Fig. 6C). In addition, the spleens from mice with suppressed NF- $\mathrm{KB}$ expression were significantly larger than controls post-chemotherapy (Fig. 6D). Histopathological analysis of spleens and livers showed highly disseminated lymphomas in the Dox-treated (p65-suppressed) animals, with infiltration to the livers after chemotherapy, whereas at this time point little infiltration was detected in the livers of "off Dox" mice (Fig. 6E). Thus, in this in vivo context, NF-кB inhibition promotes drug resistance. Importantly, NF-kB inactivation also bypassed senescence and promoted tumor progression in a murine hepatocellular carcinoma model in which p53 reactivation induces senescence (Supplemental Fig. 5; Xue et al. 2007), suggesting that the role of NF- $\mathrm{KB}$ in controlling senescence phenotypes is not unique to fibroblasts and lymphoma.

\section{Discussion}

The senescence program involves a complex interplay between cell-intrinsic and cell-extrinsic processes that influence the senescence-associated cell cycle arrest, the tissue microenvironment, and the surveillance of senescent cells by various immune system components (Kuilman and Peeper 2009). Emerging evidence indicates that the SASP can reinforce the senescence arrest and mediate cross-talk between senescent cells and other cells within their microenvironment (Krtolica et al. 2001; Acosta et al. 2008; Krizhanovsky et al. 2008; Kuilman et al. 2008). By implicating NF- $\mathrm{KB}$ as a major transcriptional modulator in senescence that is required for SASP, our study further supports the importance of the SASP for the senescence program both in vitro and in vivo. Indeed, by disrupting a key mediator of this program, we show that the SASP is important for both the cell-autonomous and non-cell-autonomous components of senescence,
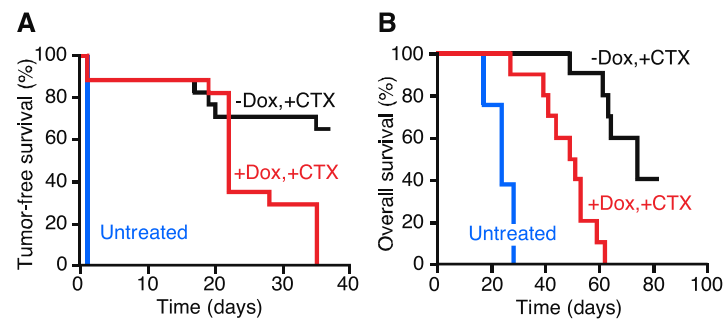

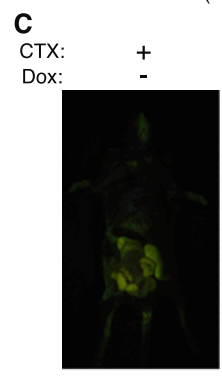

D
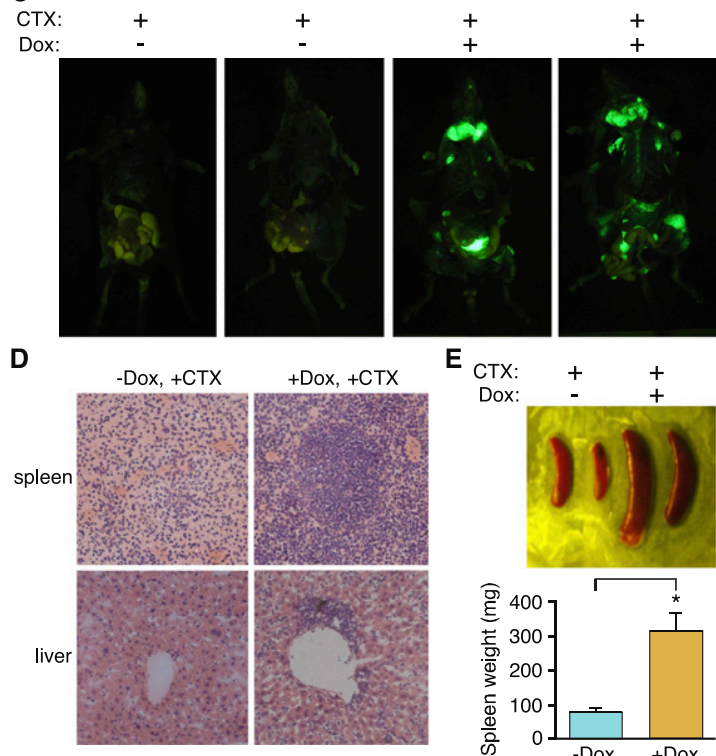

ETX:

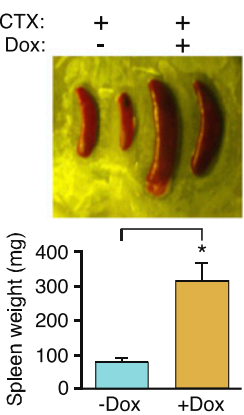

Figure 6. NF-кB inhibition leads to chemoresistance and poor survival in murine lymphomas. $(A)$ Loss of p65 function results in chemoresistant lymphomas. Kaplan-Meier analysis of tumorfree survival as measured by lymphoma palpability following CTX therapy. Day 0 equals the day of CTX treatment. Curves reflect the responsiveness of off Dox (p65-expressing) (black line, $n=15)$ and on Dox (p65 knockdown) (red line, $n=15$ ) lymphoma-bearing mice to CTX therapy. (B) Loss of p65 function leads to poor prognosis following chemotherapy. Kaplan-Meier survival analysis of on/off Dox lymphoma-bearing mice following CTX therapy ( $n=10$ for each group). Day 0 equals the day of CTX treatment. $(C)$ Lymphoma-bearing mice with or without Dox treatment were sacrificed 3 wk after CTX injection and imaged for GFP. While lymphomas in off Dox mice (p65-expressing) regressed to undetectable levels, lymphomas in on Dox mice (p65 knockdown) persisted. (D) Suppression of p65 function leads to chemoresistant lymphoblastic neoplasms. Hematoxylin and eosin staining of spleens and livers from the on/off Dox diseased animals after CTX injection. Mice on Dox (p65 knockdown) showed a much more aggressive lymphoblastic disease. (E) Spleens from the on/off Dox diseased animals after CTX injection were dissected and weighed. Values represent means + SEM from at least four independent animals per group; $\left(^{*}\right) P<0.05$ using Student's $t$-test.

stabilizing cell cycle arrest and promoting immune cell clearance. Consequently, our study has ramifications for understanding the mechanisms of senescence as they pertain to tumor suppression, and the action of NF- $\mathrm{kB}$ in cancer biology and as a therapeutic target.

Recent studies suggest that NF- $\mathrm{KB}$ can influence DNA damage responses and genomic instability during senes- 
cence and implicated the DNA damage response as a trigger for SASP (Rodier et al. 2009; Wang et al. 2009). However, in our system, p65 attenuation did not significantly alter the expression of DNA damage response genes or the accumulation of DNA damage foci following the introduction of oncogenic Ras (Supplemental Fig. 6); hence, NF$\kappa \mathrm{B}$ does not mediate the DNA damage response associated with oncogene-induced senescence. Instead, our data suggest that NF-кB directly controls the SASP by influencing the expression of NF-кB target genes.

The NF- $\mathrm{B}$ pathway is critically involved in many aspects of the immune system, from the development of immune cells and organs to the proper functioning of innate and adaptive immunity (Hayden et al. 2006; Hoffmann and Baltimore 2006). However, its role in cancer biology is less well defined and sometimes paradoxical. Beyond its role in mediating inflammatory responses that can influence cancer progression via the microenvironment (Karin 2006), most studies suggest that the cell-intrinsic activities of NF- $\mathrm{kB}$ play a pro-oncogenic role during cancer progression, perhaps through regulating survival genes in cancers. Indeed, recent work documents an essential role for NF- $\mathrm{KB}$ signaling in promoting progression of murine lung adenocarcinomas harboring activated K-ras and p53 mutants (Meylan et al. 2009).

Despite these well-established links, some studies suggest that NF- $\mathrm{B}$ can promote rather than suppress apoptosis, suggesting it might have tumor-suppressive activity (Ryan et al. 2000). Consistent with this, we detect a marked increase in NF- $\mathrm{kB}$ phosphorylation, nuclear translocation, and chromatin association during oncogene-induced senescence, and show that NF- $\mathrm{KB}$ controls a major transcriptional module that, in this context, is independent of the other major tumor suppressors: RB and $\mathrm{p} 53$. Although one report suggests that enforced NF- $\mathrm{KB}$ activity can bypass oncogene-induced senescence (Rovillain et al. 2011), we clearly see, using loss-offunction studies, that NF- $\mathrm{kB}$ actively contributes to the senescence process in vitro and in vivo. Consistent with our results, NF- $\mathrm{KB}$ is also activated and contributes to cell cycle arrest in immortalized epithelial cells following withdrawal of SV40 T antigen (Hardy et al. 2005; Rovillain et al. 2011). Moreover, superrepressor ІкB cooperates with Ras in transforming skin epithelial cells, in part by preventing down-regulation of CDK4 (Dajee et al. 2003). By identifying NF- $\mathrm{kB}$ as a master regulator of the SASP, we could use NF- $\mathrm{kB}$ inhibition to explore the impact of this "subroutine" on the biological output of the senescence program. In our in vivo lymphoma model, the apoptotic program is suppressed by Bcl-2 overexpression, such that the senescence response becomes the decisive factor for chemosensitivity and treatment outcome. Under such conditions, we see that disruption of SASP through NF$\kappa \mathrm{B}$ inhibition promotes chemoresistance of lymphomas mainly through a failure to engage the senescence response that contributes to cell cycle arrest and triggers immune clearance of the senescent cells. Consequently, animals harboring lymphomas with suppressed NF-кB show early relapse and poor survival post-therapy.
Although our in vivo work was intended to explore senescence biology in a tractable setting and not precisely recapitulate a particular disease entity, our model approximates the situation observed in patients with progressed follicular lymphoma, aggressive "double-hit" B-cell lymphomas with MYC and BCL2 translocations, and the germinal center B-cell-like (GCB) type of diffuse large B-cell lymphomas (DLBCLs) (Nogai et al. 2011). In all of these settings, Bcl-2 translocations enforce a strong apoptotic block, and recent transcriptome analyses of GCB-DLBCL indeed suggest that low NF-кB activity correlates with poor treatment outcome in patients harboring lymphomas of this subtype (Jing et al. 2011). Nonetheless, the situation is complex, as mutations leading to hyperactivation of NF- $\mathrm{kB}$ occur in the activated B-cell-like (ABC) subtype of DLBCLs, where the pro-oncogenic functions of NF-kB likely predominate (Compagno et al. 2009; Davis et al. 2010). Regardless, our studies support the notion that, in some contexts, NF-kB can have a tumor-suppressive function and imply that a component of this effect occurs through a non-cell-intrinsic mechanism.

Although the precise mechanism underlying the proand anti-oncogenic activities of NF- $\mathrm{kB}$ remains to be determined, it is interesting that several factors important for the induction of senescence have oncogenic activities in other contexts. For example, many triggers of senescence can be pro-oncogenic, including Ras and Raf. Mediators also can have an oncogenic role, such as HMGA2, MEK, and certain chromatin-modifying enzymes (Lin et al. 1998; Zhu et al. 1998; Ohtani et al. 2001; Narita et al. 2006). Perhaps these factors transmit both pro- and antioncogenic signals as part of various coordinated cellular programs-for example, to promote wound healing responses (Krizhanovsky et al. 2008) —and only when the senescence machinery is disabled do they unleash their full oncogenic potential. Consistent with this notion, both MAPK signaling and the reprogramming factor KLF4 can trigger senescence or transformation, depending on the status of components of the senescence machinery (Woods et al. 1997; Lin et al. 1998; Zhu et al. 1998; Ohtani et al. 2001; Rowland et al. 2005). Moreover, the murine lung carcinomas that respond to NF- $\mathrm{\kappa B}$ inhibition have bypassed senescence through mutant p53 (Meylan et al. 2009; Feldser et al. 2010). Navigating these context-dependent activities will be important for effectively using NF-кB inhibitors in the clinic.

\section{Materials and methods}

\section{Cell culture and gene transfer}

Human diploid IMR-90 fibroblasts (American Type Culture Collection) were cultured in Dulbecco's modified Eagle's medium (DMEM) supplemented with $10 \%$ fetal bovine serum (FBS) and penicillin and streptomycin (GIBCO). Retroviruses were packaged using Phoenix cells (G. Nolan, Stanford University, CA), and infections were performed as described (Narita et al. 2003). The infected population was selected using $2 \mu \mathrm{g} / \mathrm{mL}$ puromycin (Sigma) for $2 \mathrm{~d}, 100 \mu \mathrm{g} / \mathrm{mL}$ hygromycin B (Roche) for $3 \mathrm{~d}$, or 500 $\mu \mathrm{g} / \mathrm{mL}$ neomycin for $10 \mathrm{~d}$. For coinfection, IMR-90 cells were sequentially selected with puromycin, then hygromycin. 


\section{Senescence assays}

Senescence was induced by etoposide (100 $\mu \mathrm{M}_{\text {; }}$ Sigma) treatment or infection of IMR-90 cells with oncogenic H-Ras ${ }^{\mathrm{V} 12}$ as described (Narita et al. 2003). Senescent IMR-90 cells (postselection day 8 ) were plated on coverslips coated with $0.1 \%$ gelatin and fixed in $4 \%$ formaldehyde. For cell cycle arrest analyses, cells were labeled with BrdU (100 $\mu \mathrm{g} / \mathrm{mL}$; Sigma) and 5 -fluor-2'-deoxyuridine $(10 \mathrm{mg} / \mathrm{mL}$; Sigma $)$ for $6 \mathrm{~h}$. Nuclei incorporating BrdU were visualized by immunolabeling with anti-BrdU antibodies (1:400; BD Pharmingen) as described previously (Narita et al. 2003). For colony formation assays, 1250, 2500 , or 5000 cells were plated in each well of a six-well plate. Cells were cultured for $14 \mathrm{~d}$, then fixed with $4 \%$ formaldehyde and stained with crystal violet. Detection of SA- $\beta$-gal activity was performed as described previously at $\mathrm{pH}$ 6.0 for IMR-90 cells and $\mathrm{pH} 5.5$ for mouse tissues. Briefly, $10-\mu \mathrm{m}$ frozen sections of tissue or adherent cells were fixed with $0.5 \%$ gluteraldehyde in PBS for $15 \mathrm{~min}$, washed with PBS supplemented with $1 \mathrm{mM} \mathrm{MgCl}$, and stained for 5-6 h in PBS containing $1 \mathrm{mM} \mathrm{MgCl}$, $1 \mathrm{mg} / \mathrm{mL} \mathrm{X-Gal} \mathrm{(Roche),} \mathrm{and} 5 \mathrm{mM}$ each potassium ferricyanide (Sigma) and potassium ferrocyanide (Sigma). Sections were counterstained with eosin (Sigma). For in vitro cytotoxicity assays, growing or senescent cells were plated in six-well plates at 50,000 cells per well. YT cells $(5 \times$ $10^{5}$ ) (from DSMZ) were subsequently added to target cells. The plates were incubated under normal conditions for $12 \mathrm{~h}$, and then NK cell cytotoxicity was determined by crystal violet staining the remaining adherent cells.

\section{Immunoassays}

Immunofluorescence staining was performed as previously described (Narita et al. 2003). NF-кB p65 (C-20, Santa Cruz Biotechnologies) antibody was used. Alexa Fluor conjugates (Molecular Probes) were used as the secondary antibodies, and DNA was visualized with 4'-6-diamidino-2-phenylindole (DAPI; Vector Laboratories). Immunoblotting was carried out as described previously (Narita et al. 2003). The following antibodies were used: NF-кB p65 (C-20, Santa Cruz Biotechnologies), phospho-NF-кB p65 (Ser 536) (93H1, Cell Signaling), p53 (BD Pharmingen), p16 (H-156, Santa Cruz Biotechnologies), Ras (Ab-1, Calbiochem), p21 (C-19, Santa Cruz Biotechnologies), $\alpha$-Tubulin (B-5-1-2, Sigma), c-Myc (N-262, Santa Cruz Biotechnologies), Bcl-2 (N-19, Santa Cruz Biotechnologies), p15 (Cell Signaling), cleaved caspase-3 (Asp 175) (Cell Signaling), Histone H3 (C-16, Santa Cruz Biotechnologies), HMGB1 (Cell Signaling), and HMGA1 (Narita et al. 2006). For flow cytometry, cells were collected, resuspended with FACS buffer $15 \%$ FBS in PBS), and stained with the following antibodies: CD45R/B220, IgM, CD11b (Mac-1), NK1.1, and Ly-6G/Ly-6C (Gr-1) (BioLegend). Data were collected on an LSRII flow cytometer (BD Bioscience) and analyzed with FlowJo software (TreeStar).

\section{Gene expression analysis and RT- $q P C R$}

Total RNA was isolated using the RNeasy minikit (Qiagen), and cDNA was obtained using the TaqMan reverse transcription reagents (Applied Biosystems), used for qPCRs or for cRNA preparation (Message AmpII [Ambion]), and hybridized to U133 Plus 2.0 microarray (Affymetrix) according to the manufacturer's instructions. Data analyses were performed as previously described (Chicas et al. 2010). Gene-specific primer sets were designed using Primer Express 1.5 (sequences available on request). Real-time PCR was carried out in triplicate using SYBR
Green PCR Master Mix (Applied Biosystems) on the Roche IQ5 ICycler. GAPDH or $\beta$-actin served as endogenous normalization controls. shRNA sequences are available on request.

\section{Generation of transgenic mice with conditional shRNA expression}

We used the vectors and ES cells initially produced by the Jaenisch laboratory that enable rapid site-specific integration of regulated transgenes in ES cells. These ES cells (KH2) contain a frt-hygro-pA "homing" cassette downstream from the ColA1 gene on mouse chromosome 11, as well as a reversible tetracycline transactivator (rtTA; Tet-on) targeted into the Rosa26 locus. In these cells, FLPe recombinase mediates recombination between the FRT sites located in the ColA1 homing cassette and on the targeting vector. The correctly integrated clones were selected by hygromycin. In addition, the presence of an rtTA in these ES cells allows for rapid screening by Dox administration to activate GFP and shRNA expression. The ES cells harboring TRE-shRNA against mouse p65 were produced, and germline transgenic mice derived from these ES cells were generated using tetraploid embryo complementation.

\section{Generation of genetically defined lymphomas}

Primary pre-B-cell cultures were generated as previously described (Whitlock and Witte 1987). Briefly, bone marrow from 4- to 5-wk-old female mice carrying the Rosa-rtTA and the TREshRNA were harvested, infected with a MSCV-Bcl-2-IRES-Myc retrovirus, and plated in a pre-B-cell culture system containing RPMI 1640 medium supplemented with $10 \%$ FBS, $55 \mu \mathrm{M}$ 2-mercaptoethanol, $2 \mathrm{mM}$ glutamine, penicillin, and streptomycin (GIBCO). Transduced primary pre-B cells were initially cultured on irradiated feeder layers supplemented with recombinant mouse IL-7 ( $1 \mathrm{ng} / \mathrm{mL}$; R\&D). After 1 wk in culture, cells were expanded in the absence of feeders and IL-7. Cells were immunophenotyped by flow cytometry and determined to be $>95 \%$ pre-B cells (i.e., $\mathrm{B}^{2} 20^{+}, \mathrm{IgM}^{-}$, and negative for the myeloid/ macrophage-specific marker CD11b/Mac-1). The same procedure was used to generate lymphoma cells containing a TREshRNA against Renilla luciferase.

\section{Monitoring treatment response in vivo}

One million cells were transplanted into sublethally irradiated $\mid 6$ Gy) 4- to 5-wk-old female BL6/Ly5.1 mice. Mice were administered ciprofloxacin in the drinking water $(125 \mathrm{mg} / \mathrm{L}$; Sigma $)$. After lymphomas became palpable, mice were either administered Dox (Sigma) in water and food or left untreated. After 2 wk of Dox treatment, mice were injected intraperitoneally (i.p.) with $200 \mu \mathrm{L}$ of CTX (30 mg/mL; Sigma). Mice were sacrificed at the time indicated in each experiment after CTX injection. To prepare single-cell suspensions, spleens or lymph nodes were passed through a $100-\mu \mathrm{m}$ cell strainer. To isolate B cells, Mouse Untouched B cell Dynabeads (Invitrogen) were used according to the manufacturer's instructions. For cell proliferation analysis in vivo, mice were injected i.p. with $200 \mu \mathrm{L}$ of BrdU solution $(10 \mathrm{mg} / \mathrm{mL}$; $\mathrm{BD}$ Pharmingen) $2 \mathrm{~h}$ before sacrifice. Lymphomas were harvested, cryo-sectioned $(10 \mu \mathrm{m})$, and stained for BrdU as described previously. The Cold Spring Harbor Laboratory Animal Care and Use Committee approved all procedures described in this work.

\section{Acknowledgments}

We thank J. Simon, D. Grace, and M. Taylor for excellent technical assistance; E. Earl and L. Bianco for help with animals; 
A. Nourjanova for histology; C. Johns for microarray hybridization; and members of the Lowe laboratory for stimulating discussions. This work was supported by a fellowship from the Ellison Medical Foundation/American Federation for Aging Research and a grant from the Lauri Strauss Leukemia Foundation (to Y.C.); a fellowship entitled to Curt Engelhorn from the Angel Foundation (to C.S.); an Overseas Biomedical Training Post-doctoral Fellowship from the National Health and Medical Research Council of Australia (to J.E.B.); grants from the National Natural Science Foundation of China 160905013,91019016 , and 31061160497, to X.W.); a grant from the Leukemia and Lymphoma Society (SCOR 7015-09, to S.W.L); grants from the NIH (CA122715 and RR021239, to X.F. and B.B.; CA143177, to C.S.L.; and AG16379, to S.W.L.); and a generous gift from the Don Monti Memorial Research Foundation. S.W.L. is a Howard Hughes Medical Institute Investigator.

\section{References}

Acosta JC, O'Loghlen A, Banito A, Guijarro MV, Augert A, Raguz S, Fumagalli M, Da Costa M, Brown C, Popov N, et al. 2008. Chemokine signaling via the CXCR2 receptor reinforces senescence. Cell 133: 1006-1018.

Basseres DS, Baldwin AS. 2006. Nuclear factor- $\kappa \mathrm{B}$ and inhibitor of $\kappa \mathrm{B}$ kinase pathways in oncogenic initiation and progression. Oncogene 25: 6817-6830.

Batsi C, Markopoulou S, Vartholomatos G, Georgiou I, Kanavaros P, Gorgoulis VG, Marcu KB, Kolettas E. 2009. Chronic NF-кB activation delays RasV12-induced premature senescence of human fibroblasts by suppressing the DNA damage checkpoint response. Mech Ageing Dev 130: 409-419.

Beausejour CM, Krtolica A, Galimi F, Narita M, Lowe SW, Yaswen P, Campisi J. 2003. Reversal of human cellular senescence: roles of the p53 and p16 pathways. EMBO J 22: 4212-4222.

Campisi J. 2005. Senescent cells, tumor suppression, and organismal aging: good citizens, bad neighbors. Cell 120: 513-522.

Campisi J, d'Adda di Fagagna F. 2007. Cellular senescence: when bad things happen to good cells. Nat Rev Mol Cell Biol 8: 729-740.

Chen HZ, Tsai SY, Leone G. 2009. Emerging roles of E2Fs in cancer: an exit from cell cycle control. Nat Rev Cancer 9: 785-797.

Chicas A, Wang X, Zhang C, McCurrach M, Zhao Z, Mert O, Dickins RA, Narita M, Zhang M, Lowe SW. 2010. Dissecting the unique role of the retinoblastoma tumor suppressor during cellular senescence. Cancer Cell 17: 376-387.

Compagno M, Lim WK, Grunn A, Nandula SV, Brahmachary M, Shen Q, Bertoni F, Ponzoni M, Scandurra M, Califano A, et al. 2009. Mutations of multiple genes cause deregulation of NF-kB in diffuse large B-cell lymphoma. Nature 459: 717721.

Coppe JP, Patil CK, Rodier F, Sun Y, Munoz DP, Goldstein J, Nelson PS, Desprez PY, Campisi J. 2008. Senescence-associated secretory phenotypes reveal cell-nonautonomous functions of oncogenic RAS and the p53 tumor suppressor. PLoS Biol 6: 2853-2868.

Dajee M, Lazarov M, Zhang JY, Cai T, Green CL, Russell AJ, Marinkovich MP, Tao S, Lin Q, Kubo Y, et al. 2003. NF-кB blockade and oncogenic Ras trigger invasive human epidermal neoplasia. Nature 421: 639-643.

Davis RE, Ngo VN, Lenz G, Tolar P, Young RM, Romesser PB, Kohlhammer H, Lamy L, Zhao H, Yang Y, et al. 2010. Chronic active B-cell-receptor signalling in diffuse large B-cell lymphoma. Nature 463: 88-92.

Feldser DM, Kostova KK, Winslow MM, Taylor SE, Cashman C, Whittaker CA, Sanchez-Rivera FJ, Resnick R, Bronson R,
Hemann MT, et al. 2010. Stage-specific sensitivity to p53 restoration during lung cancer progression. Nature 468: 572 575.

Ferbeyre G, de Stanchina E, Querido E, Baptiste N, Prives C, Lowe SW. 2000. PML is induced by oncogenic ras and promotes premature senescence. Genes Dev 14: 2015-2027.

Freund A, Orjalo AV, Desprez PY, Campisi J. 2010. Inflammatory networks during cellular senescence: causes and consequences. Trends Mol Med 16: 238-246.

Hardy K, Mansfield L, Mackay A, Benvenuti S, Ismail S, Arora P, O'Hare MJ, Jat PS. 2005. Transcriptional networks and cellular senescence in human mammary fibroblasts. Mol Biol Cell 16: 943-953.

Hayden MS, West AP, Ghosh S. 2006. NF-кB and the immune response. Oncogene 25: 6758-6780.

Hoffmann A, Baltimore D. 2006. Circuitry of nuclear factor $\kappa B$ signaling. Immunol Rev 210: 171-186.

Jing H, Kase J, Dörr JR, Milanovic M, Lenze D, Grau M, Beuster G, Ji S, Reimann M, Lenz P, et al. 2011. Opposing roles of NF- $\kappa B$ in anti-cancer treatment outcome unveiled by cross-species investigations. Genes Dev (this issue). doi: 10.1101/gad.17620611.

Karin M. 2006. Nuclear factor-кB in cancer development and progression. Nature 441: 431-436.

Kortlever RM, Higgins PJ, Bernards R. 2006. Plasminogen activator inhibitor- 1 is a critical downstream target of p53 in the induction of replicative senescence. Nat Cell Biol 8: 877-884.

Krizhanovsky V, Yon M, Dickins RA, Hearn S, Simon J, Miething C, Yee H, Zender L, Lowe SW. 2008. Senescence of activated stellate cells limits liver fibrosis. Cell 134: 657-667.

Krtolica A, Parrinello S, Lockett S, Desprez PY, Campisi J. 2001. Senescent fibroblasts promote epithelial cell growth and tumorigenesis: a link between cancer and aging. Proc Natl Acad Sci 98: 12072-12077.

Kuilman T, Peeper DS. 2009. Senescence-messaging secretome: SMS-ing cellular stress. Nat Rev Cancer 9: 81-94.

Kuilman T, Michaloglou C, Vredeveld LC, Douma S, van Doorn R, Desmet CJ, Aarden LA, Mooi WJ, Peeper DS. 2008. Oncogene-induced senescence relayed by an interleukin-dependent inflammatory network. Cell 133: 1019-1031.

Kuilman T, Michaloglou C, Mooi WJ, Peeper DS. 2010. The essence of senescence. Genes Dev 24: 2463-2479.

Lin Y, Benchimol S. 1997. p53-mediated cell cycle arrest and apoptosis. Leukemia (Suppl 3) 11: 324-326.

Lin AW, Barradas M, Stone JC, van Aelst L, Serrano M, Lowe SW. 1998. Premature senescence involving p53 and p16 is activated in response to constitutive MEK/MAPK mitogenic signaling. Genes Dev 12: 3008-3019.

Malumbres M, Perez De Castro I, Hernandez MI, Jimenez M, Corral T, Pellicer A. 2000. Cellular response to oncogenic ras involves induction of the Cdk4 and Cdk6 inhibitor p15(INK4b). Mol Cell Biol 20: 2915-2925.

Mason KD, Vandenberg CJ, Scott CL, Wei AH, Cory S, Huang DC, Roberts AW. 2008. In vivo efficacy of the Bcl-2 antagonist ABT-737 against aggressive Myc-driven lymphomas. Proc Natl Acad Sci 105: 17961-17966.

Meylan E, Dooley AL, Feldser DM, Shen L, Turk E, Ouyang C, Jacks T. 2009. Requirement for NF-кB signalling in a mouse model of lung adenocarcinoma. Nature 462: 104-107.

Mooi WJ, Peeper DS. 2006. Oncogene-induced cell senescencehalting on the road to cancer. $N$ Engl J Med 355: 1037-1046.

Narita M, Nunez S, Heard E, Lin AW, Hearn SA, Spector DL, Hannon GJ, Lowe SW. 2003. Rb-mediated heterochromatin formation and silencing of E2F target genes during cellular senescence. Cell 113: 703-716.

Narita M, Krizhanovsky V, Nunez S, Chicas A, Hearn SA, Myers MP, Lowe SW. 2006. A novel role for high-mobility group 
a proteins in cellular senescence and heterochromatin formation. Cell 126: 503-514.

Nogai H, Dorken B, Lenz G. 2011. Pathogenesis of non-Hodgkin's lymphoma. J Clin Oncol 29: 1803-1811.

Ohtani N, Zebedee Z, Huot TJ, Stinson JA, Sugimoto M, Ohashi Y, Sharrocks AD, Peters G, Hara E. 2001. Opposing effects of Ets and Id proteins on p16INK4a expression during cellular senescence. Nature 409: 1067-1070.

Pearson M, Carbone R, Sebastiani C, Cioce M, Fagioli M, Saito S, Higashimoto Y, Appella E, Minucci S, Pandolfi PP, et al. 2000. PML regulates p53 acetylation and premature senescence induced by oncogenic Ras. Nature 406: 207-210.

Premsrirut PK, Dow LE, Kim SY, Camiolo M, Malone CD, Miething C, Scuoppo C, Zuber I, Dickins RA, Kogan SC, et al. 2011. A rapid and scalable system for studying gene function in mice using conditional RNA interference. Cell 145: 145-158.

Rodier F, Coppé JP, Patil CK, Hoeijmakers WA, Muñoz DP, Raza SR, Freund A, Campeau E, Davalos AR, Campisi J. 2009. Persistent DNA damage signalling triggers senescence-associated inflammatory cytokine secretion. Nat Cell Biol 11: 973-979.

Roninson IB. 2003. Tumor cell senescence in cancer treatment. Cancer Res 63: 2705-2715.

Rovillain E, Mansfield L, Caetano C, Alvarez-Fernandez M, Caballero OL, Medema RH, Hummerich H, Jat PS. 2011. Activation of nuclear factor- $\mathrm{\kappa B}$ signalling promotes cellular senescence. Oncogene 30: 2356-2366.

Rowland BD, Bernards R, Peeper DS. 2005. The KLF4 tumour suppressor is a transcriptional repressor of p53 that acts as a context-dependent oncogene. Nat Cell Biol 7: 1074-1082.

Ryan KM, Ernst MK, Rice NR, Vousden KH. 2000. Role of NF$\kappa \mathrm{B}$ in p53-mediated programmed cell death. Nature 404: 892-897.

Scaffidi P, Misteli T, Bianchi ME. 2002. Release of chromatin protein HMGB1 by necrotic cells triggers inflammation. Nature 418: 191-195.

Schmitt CA, McCurrach ME, de Stanchina E, Wallace-Brodeur RR, Lowe SW. 1999. INK4a/ARF mutations accelerate lymphomagenesis and promote chemoresistance by disabling p53. Genes Dev 13: 2670-2677.

Schmitt CA, Fridman JS, Yang M, Lee S, Baranov E, Hoffman RM, Lowe SW. 2002. A senescence program controlled by p53 and p16INK4a contributes to the outcome of cancer therapy. Cell 109: 335-346.

Serrano M, Lin AW, McCurrach ME, Beach D, Lowe SW. 1997. Oncogenic ras provokes premature cell senescence associated with accumulation of p53 and p16INK4a. Cell 88: 593-602.

Shelton DN, Chang E, Whittier PS, Choi D, Funk WD. 1999. Microarray analysis of replicative senescence. Curr Biol 9: 939-945.

te Poele RH, Okorokov AL, Jardine L, Cummings J, Joel SP. 2002. DNA damage is able to induce senescence in tumor cells in vitro and in vivo. Cancer Res 62: 1876-1883.

Wajapeyee N, Serra RW, Zhu X, Mahalingam M, Green MR. 2008. Oncogenic BRAF induces senescence and apoptosis through pathways mediated by the secreted protein IGFBP7. Cell 132: 363-374.

Wan F, Lenardo MJ. 2009. Specification of DNA binding activity of NF-kB proteins. Cold Spring Harb Perspect Biol 1: a000067. doi: 10.1101/cshperspect.a000067.

Wang J, Jacob NK, Ladner KJ, Beg A, Perko JD, Tanner SM, Liyanarachchi S, Fishel R, Guttridge DC. 2009. RelA/p65 functions to maintain cellular senescence by regulating genomic stability and DNA repair. EMBO Rep 10: 12721278 .
Whitlock CA, Witte ON. 1987. Long-term culture of murine bone marrow precursors of B lymphocytes. Methods Enzymol 150: 275-286.

Woods D, Parry D, Cherwinski H, Bosch E, Lees E, McMahon M. 1997. Raf-induced proliferation or cell cycle arrest is determined by the level of Raf activity with arrest mediated by p21Cip1. Mol Cell Biol 17: 5598-5611.

Xue W, Zender L, Miething C, Dickins RA, Hernando E, Krizhanovsky V, Cordon-Cardo C, Lowe SW. 2007. Senescence and tumour clearance is triggered by p53 restoration in murine liver carcinomas. Nature 445: 656-660.

Zhang R, Chen W, Adams PD. 2007. Molecular dissection of formation of senescence-associated heterochromatin foci. Mol Cell Biol 27: 2343-2358.

Zhu J, Woods D, McMahon M, Bishop JM. 1998. Senescence of human fibroblasts induced by oncogenic Raf. Genes Dev 12: 2997-3007.

Zong WX, Ditsworth D, Bauer DE, Wang ZQ, Thompson CB. 2004. Alkylating DNA damage stimulates a regulated form of necrotic cell death. Genes Dev 18: 1272-1282. 


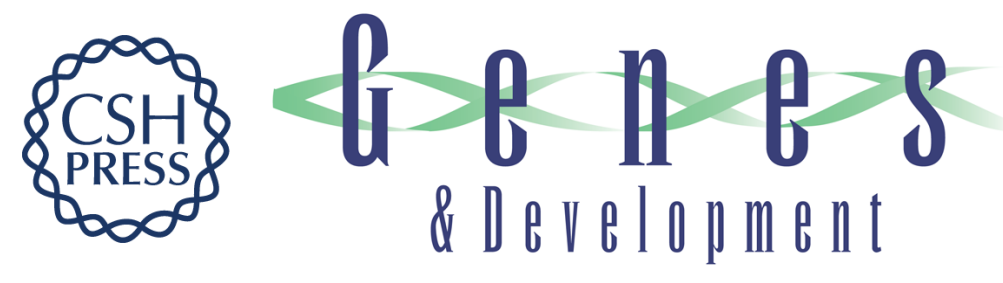

\section{Control of the senescence-associated secretory phenotype by NF- $\mathrm{KB}$ promotes senescence and enhances chemosensitivity}

Yuchen Chien, Claudio Scuoppo, Xiaowo Wang, et al.

Genes Dev. 2011, 25: originally published online October 6, 2011

Access the most recent version at doi:10.1101/gad.17276711

Supplemental http://genesdev.cshlp.org/content/suppl/2011/09/30/gad.17276711.DC1
Material

References This article cites 57 articles, 17 of which can be accessed free at:

http://genesdev.cshlp.org/content/25/20/2125.full.html\#ref-list-1

License

Email Alerting Receive free email alerts when new articles cite this article - sign up in the box at the top

Service right corner of the article or click here.

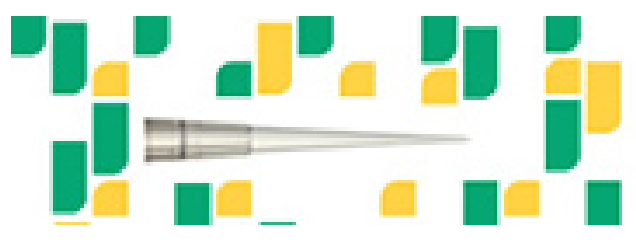

Focused on your science. 